\title{
On the Restoration of the Pre-Nostratic Language
}

\section{Kukuri Pipia}

Phasis Academy, Georgia

\begin{abstract}
The given work addresses the problem of the origin of speech and Pre-Nostratic language, which the linguists regard unsolved to this day.

Here our studies of the following issues are presented:

1. How the early men began to speak and on which basis they gave relevant names to the objects and the phenomena;

2. How did they manage to express their views?

3. What proof and the data of Pre-Nostratic language has been preserved by the Kartvelian language.

We pursue the aim of the reconstruction of the lexis of the Pre-Nostratic language, for which reason it has become necessary to study the basic words consisting of word sounds and harmonious sound complexes proved in the Kartvelian language, in other words consonants and neutral vowel $\mathrm{O}[\boldsymbol{\partial}]$, as well as harmonious sound complexes and a neutral vowel.

The work includes the Pre-Nostratic language vocabulary, as well as the method of restoration of the archetypes of the Pre-Nostratic words through the reconstruction of the Kartvelian words; these archetypes represented the word sounds and sound harmonious complexes prompted by the nature, which, for the expression of certain idea, formed on its part non-grammatical sentences. Here are presented the examples of forming modern words, as a result of uniting the archetypes forming part of the non-grammatical sentences and the following phonetic changes.
\end{abstract}

Keywords: Word sound, harmonious sound complex, Pre-Nostratic language, Kartvelian language. 


\section{Introduction}

In the beginning was the Word, and the Word was with God, and the Word was God.

The same was in the beginning with God. All things were made by him; and without him

was not anything made that was made. In him was life; and the life was the light of men.(John 1:1-4)

It is widely known that aforetime there was one uniform, single language (Genesis 11.1). However its reconstruction is considered to be impossible by the scholars, as its trace and the linguistic data are believed to be lost for the mankind beyond recall. Although, it is a well known fact that nothing is lost in the nature and it only changes. That is why the denial of the possibility to recover, reclaim something that had existed aforetime is the same as to concede to one's own failure.

From the archaeological discoveries it is clear that a man used to be a wild creature. We may suppose that at the time, a man only possessed the survival instinct and could produce inarticulate sounds but not the words that expressed any particular notions. Nevertheless, being in possession of the sensory organs, exceptional memory and the capability of development we may assume that the humans eventually developed the skill to perceive the sounds of the nature and their imitation. Probably, initially the man perceived only the simple (non compound) sounds expressed only by one consonant, while eventually he mastered more complex sounds. For instance, the sound that is emitted by hitting a stone on the stone $\mathbf{k}^{\prime} \boldsymbol{\partial} \boldsymbol{\partial}$, or a sound we hear when snowflakes fall on our head or shoulders $\mathbf{t}^{\mathbf{h}} \boldsymbol{\partial}$ which a man may have perceived earlier than a sound deer makes ərəməəə, the sound made by a hoopoe $\boldsymbol{\partial p}^{\mathbf{h}} \boldsymbol{\partial} \mathbf{p}^{\mathbf{h}} \boldsymbol{\text { }}$. Therefore, the man, imitating the nature's realities, eventually gave relevant names to these realities, which is also confirmed by the Biblical traditions: "And out of the ground the LORD God formed every beast of the field, and every fowl of the air; and brought them unto Adam to see what he would call them: and whatsoever Adam called every living creature, that was the name thereof.'" (Genesis 2.19).

It becomes clear that the primitive man started to talk imitating the sounds of nature and the phenomena and gave them relevant names. It gives us grounds to assume that the language of the primitive men was a language of the nature. While the linguistic differences within the nature's language used to be determined by the diversity of nature on the world territories, which apparently caused the differences between the speech sounds - quantitative difference of phonemes in various languages throughout the world.

Possibly due to the abovesaid dialectic differences of the nature's language occurred at the various territories of the earth, although, the nature's language, i.e. "Adam's language" had mostly to be uniform throughout the territory of the entire world. The hypothesis is proved by the existence of relevant natural sounds and words in multiple, different languages, (Bomhard, 2018), which in our opinion derive from one, basic language, the language of the nature. 
The Megrelian, i.e. Iberian language, referred today as Kartvelian language assisted us greatly in solving the given task, as it keeps quite an impressive data on Pre-Nostratic or "Adam's Language".

After the comparative analysis of corresponding Georgian Megrelian words it becomes clear that the Georgian language sprung from the maternal body of the Iberian language and grew upon it (in Megrelian, ardili/ $\mathbf{k}^{\mathrm{h}}$ ardili. Ethnic name $\mathbf{k}^{\mathbf{h}} \mathbf{a r t}^{\mathbf{h}} \mathbf{i}\left(\leftarrow \mathbf{k}^{\mathbf{h}} \mathbf{a r d i}\right.$ derived from it.

$\mathbf{t}^{\mathbf{h}} \mathbf{a b a l i}$, mentioned in Assyrian sources, t'ibari and t'iberi, in Greek and Latin sources, $\mathbf{t}^{\mathbf{n}}$ obeli, in Greek Bible, $\mathbf{t}^{\mathbf{n}}$ obeli - in Hebrew, $\mathbf{t}^{\mathbf{h}} \mathbf{u v a l i}$ in Georgian (N. Khazaradze, 1967) confirm that they have undergone different phonetic changes in different languages, despite being allomorphs derived from the common basic form $\mathbf{t}^{\mathbf{h}}$ əbərə. While the basic mom-grammarized sentence $\mathbf{t}^{\mathrm{h}} \boldsymbol{\partial}$ bə ro means [The Suopreme] Existing with supreme the light . From here derives ethnic name iberi $\left(\leftarrow \mathbf{t}^{\mathbf{h}} \mathbf{i b e r i}\right)$, and ethnic name from iberi megreli (iberi $\rightarrow$ igeri $\rightarrow$ egeri $\rightarrow$ egri $\rightarrow$ megri $\rightarrow$ megreli).

The existence of many corresponding words having derived from the common base has been proved in Georgian, Megrelian (same Iberian), Lazi - Chanian and Svani languages. (H. Fenrich, Z. Sarjveladze 2000), which is a proof that they resulted due to the divergence of common basic language. However, as only Iberian language explains the etymology of the national origin lexis in the language, named common literary Georgian, whereas other Kartvelian languages fail to do so, the Iberian language, possessing unparalleled quantity of grammatical possibilities and accordingly the richest lexical fund in the world has no alternative. (M. Dzadzmiaand others...2007), It points to the fact that the so called scheme of interrelationship Kartvelian Languages by Kurdiani and Chikobava is incorrect as well as the term "Kartvelian", as the languages implied under the term, are detached from Iberian language and not Georgian. The antecedence of the Iberian language is confirmed by the article of Acad.Takaishvili "When the state of Ibers became the Kartvelian State"(Takaishvili, 1948) and a Megrelian inscription ' $\mathrm{k}$ hiana miPorc - "I love the Universe", performed by the 3000 year old ligature in Asomtavruli and Mkhedruli script, discovered on Grakliani Hill. (Pipia K. 2017). Besides, as only the Iberian language allows to reach the depth of "Adam's language" and no other language, possessing such possibilities has been identified so far, the scheme of interrelationship between the "Adam's language", Iberian and Nostratic languages, complied with Bomhard's scheme we believe to be the following: 


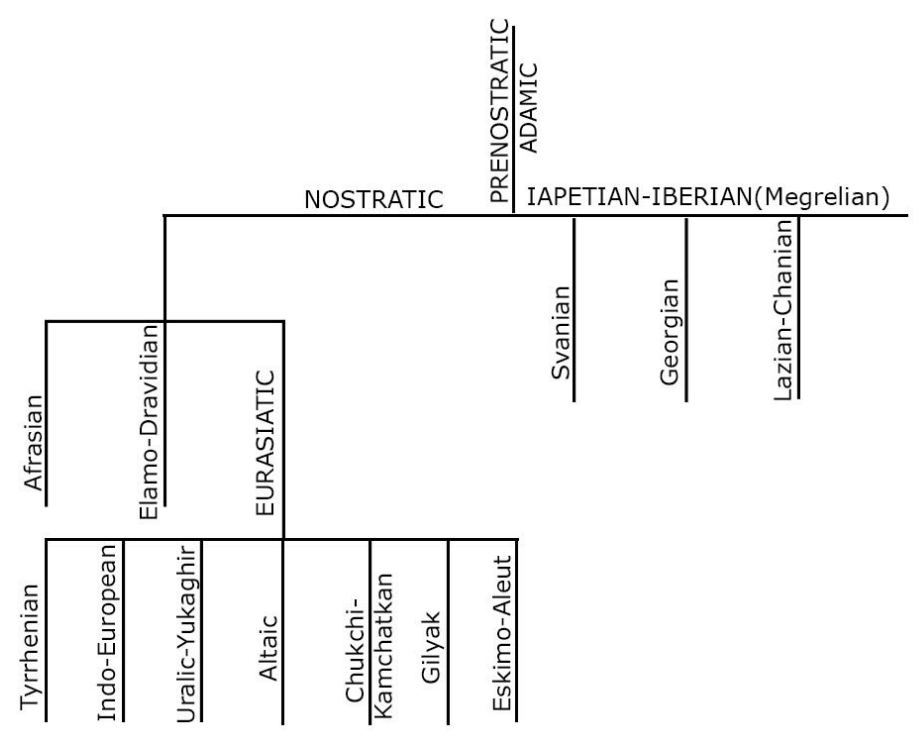

\section{Linguistic Data and scientific achievements}

As we have noted above, the scholars believed the trace and data of the language and speech origin to be lost beyond recall (G. Nebieridze, 1981, p. 50) and the interest to the language and speech studies has dwindled since 1866, but on the basis of the logic that the problem never arises if there is no way to solve it, the given interest has not been extinguished completely and our study is not conducted on empty ground..

In regards with the study of the given issue, it is important to consider the views expressed by Gamkrelidze-Machavariani: "as in early common Kartvelian vowel a had to be present by the side of the consonant, the number of syllables was determined by the number of vowels. In the common Kartvelian of the period there were no specific sonant phonemes, as the units opposed particularly to consonants and vowels as the element c was accompanied by the element ə"' (T. Gamkrelidze, G. Machavariani, 1963, p.. 370). The view expressed by the renowned linguists is a truth and it has to be pointed out that the consonant sound, pronounced separately and independently in the form of a phoneme does not exist in the nature. The consonant pronounced independently is always accompanied by the neutral vowel $\boldsymbol{\partial}$, attached to it in a natural way. Therefore not a single representative of 
any nation could pronounce the consonant sound without it, being accompanied by the $\boldsymbol{\partial}$ vowel. That is why the consonant sounds pronounced independently in Iberian language have the meanings of a complete word. That is why they are called word sounds. The same logic extends over the word harmonious complexes, which neither exist in the nature without the accompaniment of the neutral sound $\boldsymbol{\partial}$ and it gives them the importance, without which, they have no meanings, as the particular phonemes extracted from the word.

Today, in various languages there exist sound harmonious complexes, some originated in the nature and others were established within the Socius. The establishment of the latter in the socius had to be based on eliding of the $\boldsymbol{\partial}$ vowel in a more complex words derived through the merge of archetypes forming part of primeval non-grammarized sentences. Such phonetic phenomenon had to occur in certain places due to the weakness of a stress on $\boldsymbol{\partial}$ vowel. Gamkrelidze and Machavariani explain the reason of eliding of the vowel (Sincoping) in a word, in the following way: "One of the reasons for the vowel sincope may have been the presumption of the mobile dynamic stress at the early stage of the development of the common Kartvelian, through the influence of which weakening and loss of the vowels without a stress occurred." (T. Gamkrelidze. G, Machavariani, 1965, p. 370). As a result, instead of the form cəcə, sound harmonious complex ccə was achieved.

Despite the work presented by the renowned scholar T. Gamkrelidze and G. Machavariani ('System of sonants and ablaut in Kartvelian languages ), phenomenon of Megrelian language has not been thoroughly studied to this day..

Iberian language has preserved the interjection, pronounced to show extremely negative emotion, characteristic of various animals, of specific sound, before the beginning of speech by the humans, dating back to the wild life, expressing despondency and horror - vəəəəəəコ一əvəvə interjection (by women) and vo-va, va-va (by men), still used to express something negative by the word sound vo $(\rightarrow \mathbf{v a} / \mathbf{v e})$. Academician Niko Marr stated on the basis of the study of these or similar archaic words: "The Japetian language group allows us to reach the 
border lines between the Human language and animal speech, through the comparative studies.| (Niko Mar, 1923, p. 42).

Views of M. and Ts. Dzadzamia on the sounds, word origin and the speech have to be pointed out: „Megrelian consonant words are presented, as such, with only one certain condition, when they are accompanied by a half vowel ə. Without it, single consonant sounds and consonant harmonious complexes present no notion, no meaning." (Dzadzamia M., Dzadzamia Ts., 1997, p. 58); "speech sounds represent phonetic (sound) units segmented by the man, imitating the multiple inarticulate sound complexes existing in the nature, briefly - the phonemes, that are historically determined by the meanings (defined)", ...' Initial or primitive speech was actually imitation of the sounds produced by the nature, i.e. sounds expressed by the objects and the natural phenomena. In brief it was a speech in the nature's language. (Dzadzamia M., Dzadzamia Ts., 1997, pp. 204-205); "Primitive speech was a speech with the imitated basic consonant forms, namely single consonants, consonant sounds harmonious complexes and their attachments (if present) with the accompaniment of emphatic semi-vowel ə sound” (Dzadzamia M., Dzadzamia Ts., 2007, p. 93). i.e. When at the time no grammar existed, the men expressed their views through the combination of word sounds and sound harmonious complexes. However, the authors of the given reality presented the problem in a general form, hypothetically.

They present little or insufficient concrete examples. Nevertheless when the Dzadzamia authors (Father and son) made such conclusions they relied upon the word sounds and sound harmonious complexes preserved in the Iberian language to this day and multiple basic forms existing as their attachment. For instance, in Iberian language expressions preserved from the

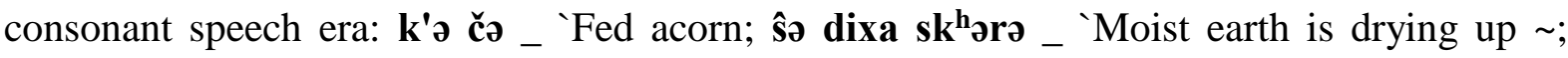
č'q'ənt'ə ?vali č'q'ərt'ə _ 'Fresh (young) cheese is being squashed etc. However did there exist in Iberian language, preserved and intensively used ten single consonant word sounds

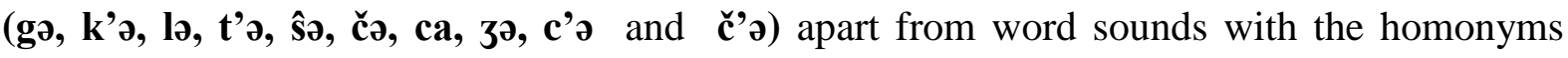
presented by 20 consonants out of 30 , how the word sounds and sound harmonious complexes came to existence; which particular realities emitted these sounds; Besides "speech sounds are phonetic units, segmented from the multiple inarticulate sound complexes existing in the nature, in short phonemes, which are historically determined by 
certain notions, meanings (specified).” (M. Dzadzamia, Ts. Dzadzamia 1997, p. 204), if in word sounds achieved by the imitation of concrete realities existing in the nature, presenting neutral vowels separately or the result of possible reconstruction of word sounds into phonemes, has not ever been studied before us.

On the basis of the fact that separate sound (phoneme) extracted from the word composition has no notion, linguistics considers the words with the notion as the unity of meaningless sound units displayed in a certain sequence: '....by the arrangement of minor units" (or with meaning K.P.). with no notion, the speaker can create the units of more complex meaning, by merging them - the words, connecting the words, he can form a sentence. Therefore on the one hand we have the sound expression units, while on the other hand - rules for the combining of the given units, the so called grammar. (T. Gamkrelidze and others, 2003. p. 28).

The conventionality theory of language origination was apparently formed on such erroneous views, which the majority of the scholars share to this day with the following dominant opinion; 'the language mostly consists of the words that denote conventional meanings of the objects and phenomena. I.e. the principles of conventionality are applied instead of iconicity principle." (G. Nebieridze, 1991, p. 17). That means that word meanings were adopted not on the basis of natural realities, but men gave un-motivated conventional names to the objects and the phenomena according their own will. In such case, errors are unavoidable and on the basis of these errors, the scholars, wishfully trying to present their language as the basic language, namely Gematrians, created an illusion of the divine, naturally ciphered origin of their language, through the selection of the words of different sound composition and artificially getting the required summed up number of characters in them. But we, along with the entire scientific world, do not share the given opinion, as big units of complex meaning - the words, were not created from smaller units void of meaning sounds (phonemes), but by the combination of comparatively smaller units prompted by the nature, bearing the meaning - and word sounds and sound harmonious complexes, which after turning determining neutral vowel a into a complete vowel are present today in the words as syllables. 


\section{Establishing the origin of sound harmonious complexes}

For the reconstruction of the real picture of Pre-Nostratic, or "Adam's Language" speech it has become necessary to set whether the harmonious complex under the study is a sound harmonious complex existing in the nature or result of later, phonetic changes, characteristic for the socius, as it is known that the harmonious complex $\mathbf{c}_{1} \mathbf{c}_{2}$ a, existing in the nature, doesn't break into separate $\mathbf{c}_{1} \boldsymbol{\partial}$ and $\mathbf{c}_{2} \boldsymbol{\partial}$ word sounds. As it was possible to pronounce $\mathbf{c}_{1} \boldsymbol{\partial} \mathbf{c}_{2} \boldsymbol{\partial}$ forms in a reversed way $\mathbf{c}_{2} \boldsymbol{\partial} \mathbf{c}_{1} \boldsymbol{\partial}$ and later (after the merging of the word sounds) due to the weakness of a stress on $\boldsymbol{\partial}$ vowel between the two consonants, eliding of the given vowel may have occurred. We also have reversed forms of the consonant sound harmonious complexes c1c2s and c2c1s, for example bro-li (crystal) and rbi -li (soft), rk $\mathbf{r k}^{\mathbf{h}} \mathbf{a}$ (horn) and $\mathbf{k}^{\mathbf{h}}$ ro-mi (chrome) etc. Similar reversed sound harmonious complexes do not exist in the world. Therefore, there do not exist t'q'a, క̌yo, čxə and etc. Reversed forms of natural

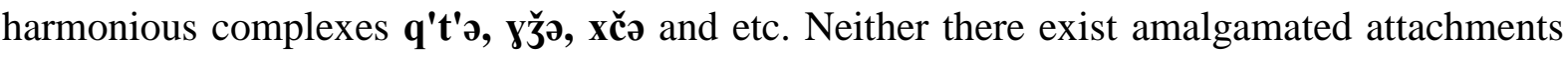
of word sounds and sound harmonious complexes, which give us certain meaning. For example cəcə and ccәcə forms. Such merging used to occur at the stage following the primeval speech of a man. I.e. if there exists the reversed form of $\mathbf{c}_{1} \mathbf{c}_{2} \boldsymbol{\partial}-\mathbf{c}_{2} \mathbf{c}_{1} \boldsymbol{\partial}$, it means that $\boldsymbol{\partial}$ vowel with $\mathbf{c}_{1}$, or $\mathbf{c}_{2}$ has elided. Despite the fact that initially it originated in the form of $\mathbf{c}_{1} \partial \mathbf{c}_{2} \partial$ or $\mathbf{c}_{2} ә \mathbf{c}_{1} \partial$.

It is possible that from the beginning to this day, throughout the millennia, under the influence of turbulent past and cataclysms, not all initially existing natures prompted word sounds and all speech sounds (phonemes) have been preserved, but on the basis of the linguistic data preserved in Megrelian (same Iberian) language, it becomes possible to reconstruct the main lexical fund of the Pre-Nostratic language, or the first common or "Adam's Language". This lexical fund was possibly limited to the word sounds formed by 30 (or more) consonants existing in Megrelian (if there existed over 30 consonants), homonyms and sound harmonious complexes. Until that we find it necessary to present several examples of the formation of the latter. 


\section{Origination of word sounds and sound harmonious complexes}

We have prepared all the assumed examples of the presumed origin of word sounds and sound harmonious complexes for the book soon to be published titled 'The first alphabet of the mankind." Here we present only several examples:

1. If we quickly stretch a springy (solid) rope or a tightly stretched string between the two points, after pulling the rope we shall hear word sound bəəə. In the first place tying, connection took place, while in the other case the tying, connection silence, peace was broken, during which the given realiities issued and we heard a sound complex bəəə. That is why the sound complex bə/bəəə

2. If we are in a cozy, comfortable environment and snow flakes fall on our head and shoulders we shall periodically hear the sound complex $\mathbf{t}^{\mathbf{h}} \boldsymbol{\partial}-\mathbf{t}^{\mathbf{h}} \boldsymbol{\partial}-\mathbf{t}^{\mathbf{h}} \boldsymbol{\partial} \ldots$ if we pronounce

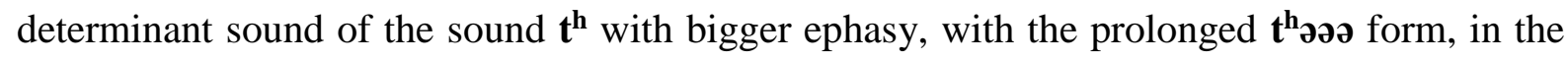
shape of snow, water, or the phenomenon of light standard, with the aim to deliver information to someone, this information becomes more persuasive. Therefore the word sound $\mathbf{t}^{\mathbf{h}} \boldsymbol{\partial} / \mathbf{t}^{\mathbf{h}} \boldsymbol{\text { əəəə)}}$, after pronouncing $\mathbf{t}^{\mathbf{h}}$ oua $\rightarrow \mathbf{t}^{\mathbf{h}} \mathbf{o v a}$ (snowing), figuratively assumes the meaning of arriving light. Word sound $\mathbf{t}^{\mathbf{t}} \boldsymbol{\partial}$ in Iberian language is 3rd person verb. And expresses the finished event, the snow flake, fallen once will not fall again. Therefore in

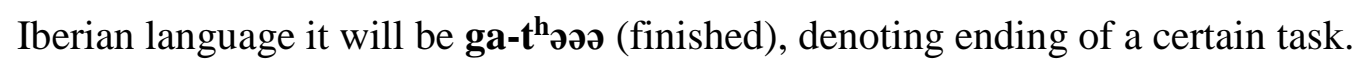


3. rərərərərə... prolonged sound complex we shall hear during the movement of the invisible reality, around us at a high speed. It should be pointed out that all the rest 29 (consonant) word sounds are emitted by the visible realities. Apparently, due to the fact of being different and special the word sound ro, after pronouncing re (is) was given the function of confirming the presence pf other realities.

4. overripe fruit, being left on the branch in an inaproachable place, with its appetizing smell, seems to be whole and palatable from the distance, but with a slight shake of the branch it will drop to the ground and squashing will produce the sound harmonious complex

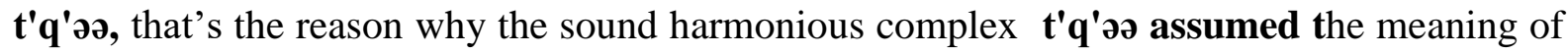
false, imaginary. Meaning of Lying, deceitful false. From it Iberian word t'q'ura (lie has come to exsistence): $\mathbf{t}^{\prime} \mathbf{q}^{\prime}$ 'əre $\rightarrow \mathbf{t}^{\prime} \mathbf{q}^{\prime} \mathbf{u r e} \rightarrow \mathbf{t}^{\prime} \mathbf{q}^{\prime} \mathbf{u r a}$ and the Georgian $\mathbf{t}^{\prime} \mathbf{q}^{\prime} \mathbf{u i l i}$ (a lie): t'q'orre $\rightarrow t^{\prime} q^{\prime}$ uire $\rightarrow t^{\prime} q$ 'uile $\rightarrow t^{\prime} q$ 'uili.

5. If we squeeze a fat chicken, live or plucked and cleaned, we shall hear the sound harmonious complex $3 \mathbf{\gamma}$, which can't be said on a lean chicken. The chicken that does not produce such sound harmonious complex is not considered to be edible. In Iberian language it is said: dir-3yə, to which Georgian ga-3ya corresponds, in English saturated.

As for the origin of the sounds (phonemes), as a result of the reconstruction of word sound consonants and neutral vowel, it is easier to present them as separate, units without the meaning, than their segmentation from inarticulate sound complexes".

\section{Pre-Nostratic or "Adam's Language" vocabulary}

We believe that there does not exist a complete vocabulary and it just can not exist, as in a short amount of time a new word may come to existence. It is also possible a word to lose its meaniing and be dropped out of use, in time. Thus, it is only natural that the linguistic fund of "Adam's language", consisting of the old basic forms (word sounds and sound harmonious complexes) may not be complete, but it offers us approximate picture of the speech of the period. 
As mentioned above, the primitive speech was a speech that involved immitation with single consonant forms, i.e word sounds, while expressing deeper views with their attachments is a more subsequent phenomenoon.

In our view the primitive language lexis had to be similar to the one below;

a) word sounds:

bo 1. `tied $\sim$; Cxou b, (čxou bə) _ `the cow is tied $\sim$;

2. `-is hung $\sim$; guda jas muko-b, (guda žas muk'o - bə) _ 'leather bag is hanging on a tree $\sim$;

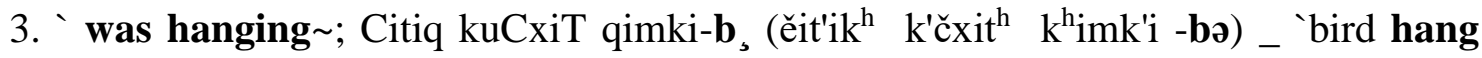
from the branch with its foot $\sim$; here all three words (atied, hanging and was hanging) express tying, connection in general;

4. `poured out $\sim$; gegna-b, (gegna-bə) _ `poured out, poured down $\sim$;

5. ‘poured”; qigni-b, $\left(\mathrm{k}^{\mathrm{h}}\right.$ igni - bə) _ ‘poured on . Poured, pouring in general.

gə. 1. woodcock;

2. 'looks like $\sim$; squa mumas $\mathbf{g}_{\text {s }}\left(\mathrm{sk}^{\mathrm{h}} \mathrm{ua}\right.$ mumas $\left.\mathbf{g ə}\right)$ _ `son looks like father $\sim$;

3. `built $\sim$; giorgiq pude a-g, (Giorgik ${ }^{\mathrm{h}}$ Pude a-gə) _ `Giorgi built a house $\sim$;

4. `won $\sim$; petreq lauafi mi-g, $\left(\mathrm{P}^{\prime} \operatorname{etrek}^{\mathrm{h}}\right.$ laPaphi mi-gə) _ `Petre won a game $\sim$;

5. ‘won from ; petreq layafi mu-g, $\left(\mathrm{P}^{\prime} \mathrm{etrek}^{\mathrm{h}}\right.$ la Paphi mu-ga) _ "Petre won the game from $\mathrm{sb} \sim$;

6. `to sheath ; yama orCxes qala-g, (q'ama orčxes khala-gə) _ `Sheathed a sword ;

7. ‘return grace $\sim$; mardi gina-g, (mardi gina-ga) _ ‘returned grace $\sim$;

8. `repaid $\sim$; vali gini-g, (vali gini-go) _ `repaid debt ;

9. ‘put on, (-irgo) ; xeSTaTmani qimi-g, (xešth $\mathrm{at}^{\mathrm{h}}$ mani $\mathrm{k}^{\mathrm{h}}$ imi-gə) _ ‘put on gloves (fitted on) ;

10. 'hit $\sim$; keti qimio-g, (k'et'i k'imio-ga) _ 'hit sb., with a bat ;

11. `find way out $\sim$; uryi tyaSe ZiuT gs Sa-g, (urq'i tq'aše ziut ${ }^{\mathrm{h}}$ gaša-gə) _.'hardly found the way out from a dense forest"; 
12. `Earth $;$ ga/ge/gi (ga/ge/gi) _ `planet earth .

də. 1. `-placed $\sim$; Wirqa tabakis qigla-d, (čirk ${ }^{\mathrm{h}} \mathrm{a}$ tabak'is $\mathrm{k}^{\mathrm{h}}$ igla-də) _ `placed glass on the table $\sim$;

2. "put on" qimi-d (č'ap"ula k $\mathrm{k}^{\mathrm{h}}$ imi-də) _ "put on shoes";

3. 'left- ; ase i-d (ase i-də) _ _ just left $\sim$.

və. 1. `va/vo/va interjection expression of show sorrow, mourning, unpleasant experience. `vəəəəəvə - vəvə KKeening of Iberian women; ‘vo-va, va-va _ men;

2. `va/ve $\sim$; va-re (va re) _ is not $\sim$; ve-lapafu $\left(\mathbf{v e}-\right.$ laPap $\left.^{\mathrm{h}} \mathrm{u}\right)$ _ `did not play .

zə. 1. `kneaded $\sim$; comi $\mathbf{z}_{s}$ (comi zo) _ `Kneaded dough $\sim$;

2. `is burning, is on $\sim \mathrm{daCx}_{s}$ ri $\mathbf{z}_{s}$ (dačxəri $\mathbf{z o}$ ) _ `Fireis on $\sim$

3. `-reconciled $\sim$; maCxuperi boSefi ga- $\mathbf{z}_{s s}$ (mačxup'eri bošephi ga-zə) _ 'reconciled the fighting children $\sim$.

hə. Word sound $\mathbf{h}_{\text {s }}$ (ho) conveys the name of the material mass, which we breath, smell and to which we listen, without which no living creature can survive for more then two minutes. And the one that is not pronounced, it is breathed out.

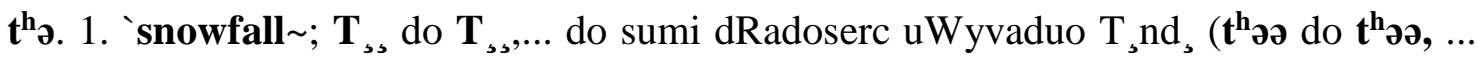

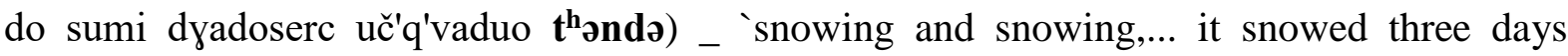
without a stop. $\sim$;

2. ‘family ; ibdaT Cqimi Ti-Sa (ibdat ${ }^{\mathrm{h}} \mathrm{čk}^{\mathrm{h}}$ imi $\mathbf{t}^{\mathrm{h}} \mathbf{i}$-ša) _ `let’s go ti my family .

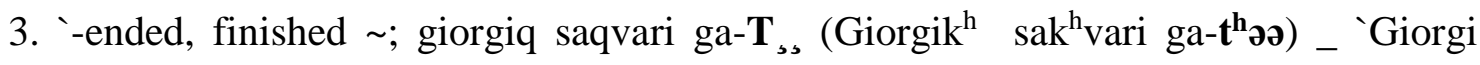
finished work /ended it $\sim$.

k’ə. 1. acorn_oaknut;

2. `-kept to himself $\sim$; besoq dixa mi-k , $_{s,}$ Besok $^{\mathrm{h}}$ dixa mi-k’əə) ${ }_{-}{ }^{` B e s o}$ occupied the land ; 
3. '-tempered ; petreq yama jgiro gagmo-kver, (P'et'rek ${ }^{\mathrm{h}}$ q'ama ǰgiro gagmo-k'verə) _ 'Petre tempered the sword well $\sim$.

lo. 1. 'falls down $\sim$; qua dixas $\mathbf{l}_{\text {, }}\left(\mathrm{k}^{\mathrm{h}} \mathrm{ua}\right.$ dixas $\left.\mathbf{l o}\right)$ _ `stone falls down $\sim$. Falling. in general.

2. 'walked $\sim$; iq mTeli qiana mi-l, $\left(\mathrm{ik}^{\mathrm{h}} \mathrm{mt}^{\mathrm{h}} \mathrm{eli} \mathrm{k}^{\mathrm{h}}\right.$ iana mi-lə) ${ }_{-}$'he walked around the world ;

3. '-studied, investigated $\sim$; giorgiq i akani jgiro gi-l, $\left(\right.$ Giorgik $^{\mathrm{h}}$ i ak'ani 3 giro gi-lə) 'giorgi investigated the area, studied the area well .

mə. 1. ' $\mathrm{m}_{s} / \mathrm{ma} \sim(\mathrm{mə} / \mathrm{ma})_{\text {_ }}$ personal pronoun _ ' $\mathrm{I} \sim$;

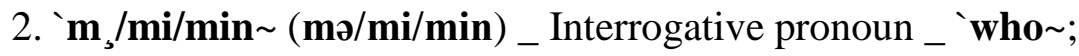

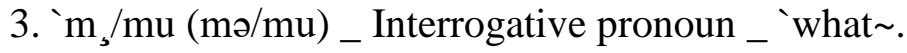

nə. 1. 'n $/$ /na (nə/na) _ 'water ; in fugurative sense _ 'The sourse of life $\sim$, or, 'God creator ;

2. '-hurt $\sim$; baRanas Tofurq e-n, (bayanas $\left.\mathrm{t}^{\mathrm{h}} \mathrm{op}^{\mathrm{h}} \mathrm{urk}^{\mathrm{h}} \mathrm{e}-\mathbf{n} \boldsymbol{\text { ə }}\right)$ - 'Honey hurt the baby .

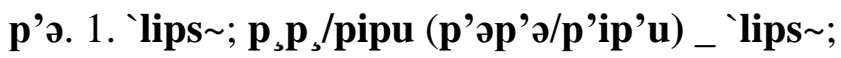

2. 'made $\sim$; ma RoronTiq ps, (ma yoront ${ }^{\mathrm{h}} \mathrm{ik}^{\mathrm{h}} \mathbf{p}$ 'ə) _ 'God made me (created).

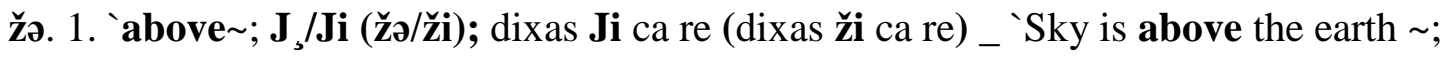

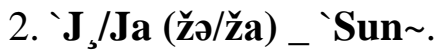

rə. ' $\mathbf{r}_{s} / \mathbf{r e} \sim(\text { rə/re })_{-}$'Is .

sə. 'Urinate , in general, to urinate. figuratively: relief, facilitation pleasure, bliss.

t'ว. 1. udder;

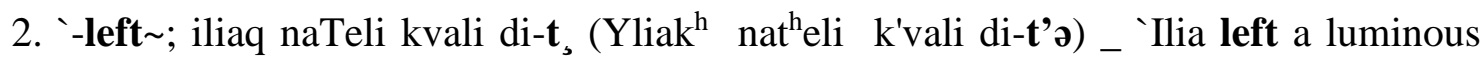
$\operatorname{mark} \sim$

3. 'forgiveness $\sim$; RoronTiq coda miu-t , (yoront $^{\mathrm{h}} \mathrm{ik}^{\mathrm{h}}$ coda miu-t'ə) - 'God forgave him, any $\sin \sim$.

4. '-breath last breath ; lexiq Suri go-t ss $\left(\right.$ lexik $^{\mathrm{h}}$ šuri go-t'əə) _ 'The sick breathed last breath ; 
5. '-freed (set free) ; baRanaq Citi gou-t (bayanak $^{\mathrm{h}}$ čit'i gou-tə) _ 'Child freed a bird $\sim($ set free $)$;

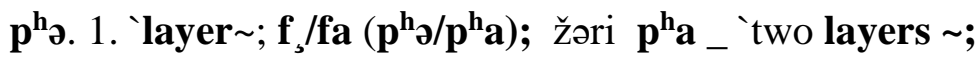

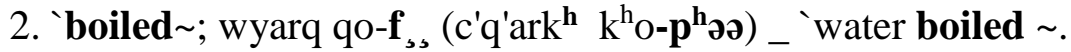

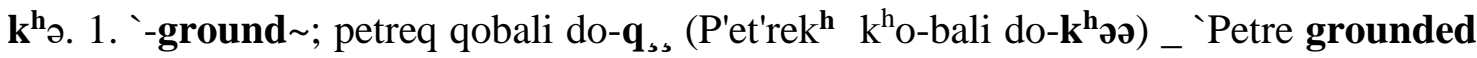
wheat $\sim$;

2. `Do ; zvambaq i-q, e saqme (Zvambak ${ }^{\mathbf{h}}$ i-k $\mathbf{k}^{\mathbf{h}}$ əə e sak $\left.{ }^{\mathbf{h}} \mathrm{me}\right)$ - 'Zvamba did it .

уə. 1. 'owl _ night bird; $\mathrm{R}_{s} / \mathrm{Ru}$ ( $\left.\mathrm{\gamma} / \mathrm{\gamma u}\right)$ In Iberian language the bird was given a name according the sound complexes it produces $\mathbf{R}_{s}-\mathbf{R}_{s s}-\mathbf{R}_{s s s s}$ (Уə-Уəə--уәәәәә) immitating;

2. '-took ; qeTiq wigni mide-R, $\left(\mathrm{K}^{\mathrm{h}} \mathrm{et}^{\mathrm{h}} \mathrm{ik}^{\mathrm{h}}\right.$ c'igni mid-yə) $^{-}$Keti took the book ;

3. '-brought $\sim$; gogiq oRali qimi-R, (Gogik ${ }^{\mathrm{h}}$ oyali k $\left.{ }^{\mathrm{h}} \mathrm{imi}-\mathbf{- y}\right)$ _ 'Gogi brought the load here $\sim$.

q'ə. 'shoutediyvira ; aWou do $\mathbf{y}_{s,}$ (ač'ou do q'əə) _ 'It hurt and he shouted .

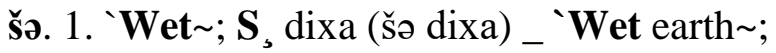

2. 'remembers $\sim$; is ifreli $\mathbf{S}_{s}$ (is ip ${ }^{\mathrm{h}}$ reli šo ) _ 'he remembers everything . In a general form, remembrance, memory;

3. '-walked / vlida ; Cqaras mi-S, (̌̌k $\mathrm{k}^{\mathrm{h}}$ aras mi-šə $)$ _ 'walked fast/walked ;

4. 'drank ; Tamadaq breli Rvini $\mathbf{S}_{s} / \mathbf{S u}\left(\mathrm{t}^{\mathrm{h}}\right.$ amadak $^{\mathrm{h}}$ breli jvini ras šə/šu) _ 'Toastmaster drank much wine ;

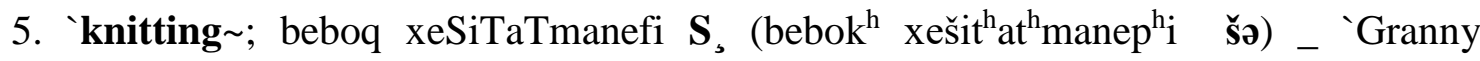
knitted mittens $\sim$.

čə. 1. `Fed ; oWkumali $\mathbf{C}_{\text {s }}$ (očk'umali čə) _ `Fed sb. . In general alimentated;

2. '-gave away ; sikeTe go-C, (sik'et ${ }^{\mathrm{h}} \mathrm{e}$ go-čə) _ 'shared kindness ;

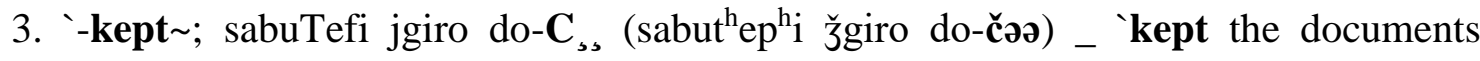
safely .

cə. 1. `elm _tree specie;

2. 'beat up ; ketiT $\mathbf{c}_{s}\left(\mathrm{k}^{\prime} \mathrm{et}^{\prime} \mathrm{it}^{\mathrm{h}} \mathbf{c o}\right)$ _ 'beat up with a bat $\sim$;

3. 'paid ; pativi c, (p'at'ii cə) _ 'Paid respect . 


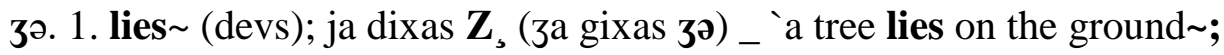

2. 'graze $\sim$; cxenq ndolo $\mathbf{Z}_{s,}\left(\text { cxenk }^{\mathrm{h}} \text { ndolo zəə) }\right)_{-}$'horse grazes in the field $\sim$

c'ə. 1. 'this year ; w, jgiri mosavali ipuafu (c'ə ǰgiri mosavali i?uap ${ }^{\mathrm{h}} \mathrm{u}$ ) _ 'harvest is good this year ;

2. 'suckled ; $\mathrm{Cq}_{s} \mathrm{Cq}_{s} \mathrm{q} \mathrm{ZuZu} \mathrm{w}_{s,}\left(\check{c ̌ k}^{\mathrm{h}} \partial \mathrm{c̆k}^{\mathrm{h}} \partial \mathrm{k}^{\mathrm{h}}\right.$ zuzu c'əə) _ 'The baby suckled ;

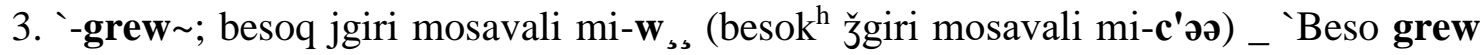
good harvest $\sim$.

с̌’ə. 1. 'intestine ;

2. '-sew ; kaba do-W

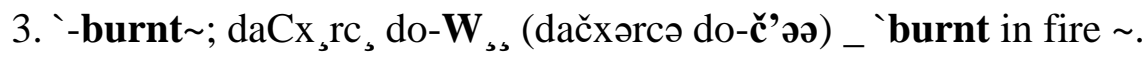
$q^{\text {h}}$ ə. 1. handful;

2. 'overthrew (knocked down) ; dudigime $\tilde{\mathbf{A}}_{s} / \tilde{A} \mathbf{u}$ (dudigime $\mathbf{q}^{\mathrm{h}} / \mathbf{q}^{\mathrm{h}} \mathbf{u}$ ) overthrown ;

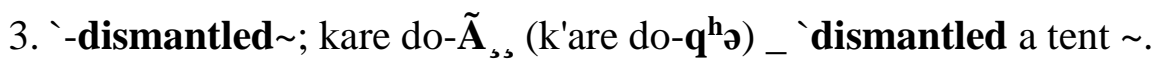

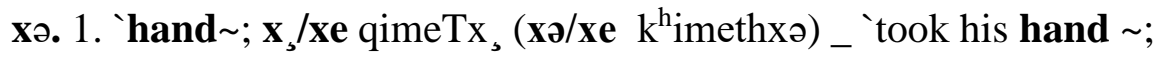

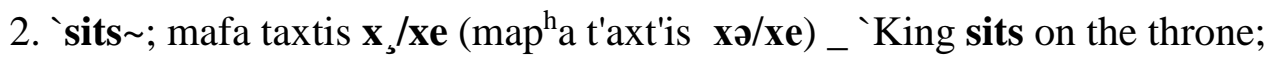

3. 'gave birth $\sim$; Txaq qacari $x_{s}\left(\mathrm{t}^{\mathrm{h}} \mathrm{xak}^{\mathrm{h}} \mathrm{k}^{\mathrm{h}}\right.$ acari $\left.\mathbf{x} \boldsymbol{\prime}\right)$ - 'a goat gave birth $\sim$.

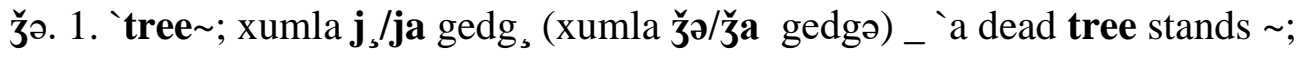

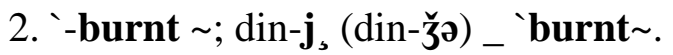

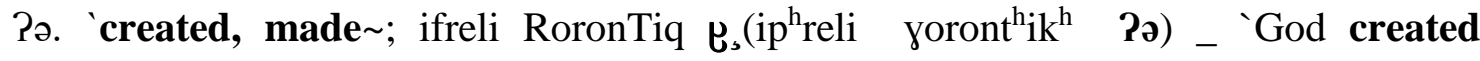
everything .

b) Sound harmonious complexes existed in the nature:

t'q'ə. 'liar ; ty , re (t'q'ə re) _ is a liar ; 


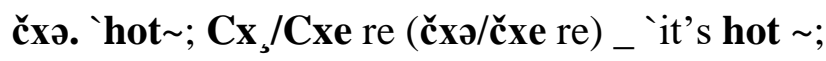

зуә. Sound harmonious complexes expressing something fat, well-fed (gam-3ya-ris);

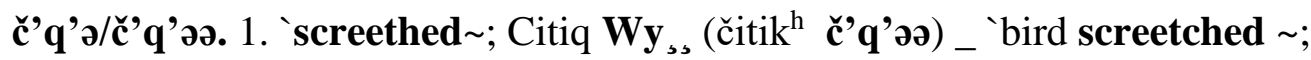

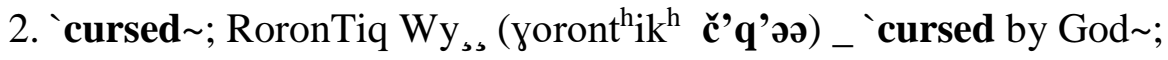

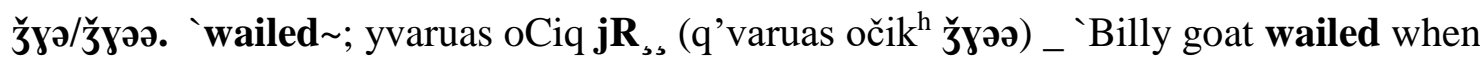
castrated .

Besides there do exist sound harmonious complexes sc'ə, p p $^{\mathrm{h}} \mathrm{x}, \mathrm{p}$ 'q'ə, cxə da c'q'ə, which seem to be of natural origon, but we havent't yet sought out the realities emitting such complexes. Complexes confirmed in Georgian language cxə and c'q'ə of natural origin have to be equivalent forms of čxə da č'q'ə complexes confirmed in Iberian language.

\section{Method of the restoration of archetypes and sentences of Pre- Nostratic language through the reconstruction of Kartvelian words.}

It is noteworthy that in Megrelian (Iberian) language 86 homomyms are presented in total through 30 wordsounds constreucted on 30 existing consonants. Among them $15-$ nouns, 63 3rd person verbs., 1 - interjection, 1 - particle, 3 - pronouns, 2 adverbs and 1 adjective. i.e. signs of grammatization were initially involved in the wordsounds and sound harmonious complexes. Therefore, although rarely, we encounter in Pre-Nostratic language well grammatized and slightly grammatized archaic sentences as well.

In order to reconstruct archetypes and sentences of the Pre-Nostratic or Nature's language we have to set whether the words under the study are of relatively later formations or have been cenceived in the era of the functioning of Pre-Nostratic language . For which reason we should replace all the vowels of the studied word with the neutral a vowel and we may get three types of archaic sentences:

a) when the archaic sentence includes only the archetypes presented by wordsounds.;

b) when the archaic sentemce includes one or more word sounds and sound harmmonious complex existing in the nature;

c) when archaic sentence includes one or more wordsound and sound harmonious complex born in an archaic era, which is a result of syncopy of the neutral ə vowel between 
the two consonants, having come to existence due to the merging of archetypes presented by wordsounds in the same sentence.

After the reconstruction of the sound harmonios complexes, dated back to when they were conceived, archaic sentence represented in point"a" is received.

The given method only allows to determine etymology and meaning of the words that came into existence during the functioning of Pre-Nostratic language. I.e. it would allow to restore the non-grammarized sentences built by archetypes, through the restoration of the words that are in use to this day (but have originated in the archaic period). If it turns out that the notion of the latter received through the grammarization at the modern level accurately determines the meaning of the word under the study, it will prove that it has been conceived in the era of the functioning of Pre-Nostratic language and the archetypes and the sentence are restored (reconstructed) correctly.

For the reconstruction of true archetype of the studied words of the conception period it is always necessary to take into consideration the possible phenomenon of ablaut.

\section{Restoration of the speech forms of Pre-Nostratic language}

In order to clarify the abovesaid, we should consider several examples:

a) From the vocabulary of Nostratic (latin nostratos _ our) languages:

1. Proto-Indo-European * $\mathrm{b}^{\circ}$ or- $/{ }^{*} \mathrm{~b}^{\circ}{ }_{\mathrm{r}}$ - 'to bore, to pierce'; Proto-Afrasian *bur- 'to bore, to pierce'; Proto-Uralic *pura 'borer, auger'; Proto-Dravidian *pur- '(vb.) to bore, to perforate; (n.) borer, gimlet'; Proto-Altaic *burV- 'to bore through, to pierce'. Cf. Sumerian bùr 'to bore through, to pierce' (Bomhard, vol. I, 2018, p. 16). In Georgian buryva // buryua; In Megrelian rxuala _ boring, piercing.

Here, the the equivalence of the bases of rxu and $\mathbf{r} \gamma \mathbf{u}$ is important, the initial form of which has to be rə xə, which, at the level of modern speech could be imagined in the following way: is (rə) birth (xə), or there is a [new desired reality] birth. And indeed through drilling/boring, a new and desired, more complete reality is born. 
2. Proto-Kartvelian *baba 'father': Georgian babua- 'grandfather'; Laz baba- 'father, dad'; Mingrelian baba- 'father, dad'; Svan baba- 'dad'. Klimov 1964:47 *baba-; Schmidt 1962:94. (Bomhard, Vol. II, 2018, p. 9).

The base of the mention corresponding words has to be bəbə, double bə, which directly means binding, link, connection, biological connection is implied, continuity: Son - father grandfather. Georgian ba-všvi and bi-č'i, Megrel. ba-yanaDand bo-ši, Laz. be-re denote biological connection, son.

3. In Aramaic language there is kerïm (bark, leather) equivalent to Georgian $\mathbf{k}^{\mathbf{h}} \mathbf{e r k}^{\mathbf{h}} \mathbf{i}$, in Sahara Berberic Tuareg there is a-urum (a bark); Muab Chad language group has kuroro (shell, bark); Latin and old Russian k'ora; In Old Mongolian körü - süm (skin); In Japanese k'ara _ shell, bark (Dolgopolsky Долгопольский, 1971-1972, p. 117).

In our opinion, the word $\mathbf{k}^{\mathbf{h}} \mathbf{e r k}^{\mathbf{h}} \mathbf{i}$ and its equivalent forms in various languages have been derived from the basic form $\mathbf{k}^{\mathbf{h}} \boldsymbol{\partial}$ rə $\mathbf{k}^{\mathbf{h}} \boldsymbol{\partial} \rightarrow \mathbf{k}^{\mathbf{h}} \mathbf{e r k ^ { h }} \mathbf{i}$, where $\mathbf{k}^{\mathbf{h}} \boldsymbol{\partial}$ means making $\mathbf{r} \boldsymbol{\partial}$ - is. Then $\mathbf{k}^{\mathbf{h}}$ ə $\mathbf{r} \boldsymbol{~} \mathbf{k}^{\mathbf{h}} \boldsymbol{\partial} / / \mathbf{k}^{\mathbf{h}} \mathbf{e r k} \mathbf{k}^{\mathbf{h}} \mathbf{i}$ means creator(maker) is Creator. Thus, truly the bark is the creator of wood without which the growth of the wood and its development and creation are impossible.

b) From Russian:

In Russian we have the word lečenie _ treatment (medical). If the word was conceived in the era of uniform speech, it had to be conceived in a form lo čə no. The basic form denoted by the similar connected form does not exist in the nature. In Megrelian we have separate word sounds lə _ falling down, falling; čə _ fed to, alimentate; nə _ Water, Water Source of Life. Thus if in the era of uniform speech they used to pronounce jointly the words falling + feeding + source of life it means that they wanted to say: feeding the fallen with the source of life. Even on the level of the contemporary speech Feeding the fallen, or a sick person with the source of life may only mean treatment.

2. k'niga _ a book. Its basic form had to be k'ə nə gə, where k'ə in Megrelian means tempering, nə _ water (directly meaning), figuratively source of wisdom, gə _ build, 
General form, building, therefore the sentence consisting of these words is of the following essence: source built by [mind] tempering [of wisdom] is nothing else but a book.

\section{c) From Hebrew:}

1. In Hebrew we have a word daluti _ beggar. Its basic form had to be do lə t'ə, whre do is the $3^{\text {rd }}$ person verb and means put, in a general form placement (put), lo, as we have mentioned means falling, $\mathbf{t}$ ’ is also $3^{\text {rd }}$ person verb and means give birth, general form, birth. Then dalut'i $\leftarrow$ də lə t'ə means placement (put) _ born to be fallen, i.e. for inactive falling, doomed to be a beggar.

2. Jewish Cabalists write that the language initially was called $\mathbf{t}^{\text {hanaxa. Thora and }}$ sacred scriptures were written in this language, but they fail to explain convincingly the etymology of the given word. The word $\mathbf{t}^{\mathbf{h}}$ anaxa is written in Hebrew only with consonant sounds $\mathbf{t}^{\mathrm{h}} \mathbf{n x}$ where $\mathbf{t}^{\mathbf{h}}$ in their opinion means $\mathbf{t}^{\mathrm{h}}$ ora, Pentateuch, $\mathbf{n}$ - nevim (Prophets), and $\mathbf{x}$, means k't'uvim (Scriptures). (I apologize to the readers for being unable to explain what is the connection of the sound $\mathbf{x}$ with the word $\mathbf{k}^{\prime} \mathbf{t}^{\prime} \mathbf{u v i m}$ ).

In Iberian language $\mathbf{t}^{\mathrm{h}}$ in the word $\mathbf{t}^{\mathrm{h}}$ ənəxə means light (Supreme is implied, the divine wisdom, nə _ is water, source of life, figuratively God - creator. xə-is also a $3^{\text {rd }}$ person verb and means giving birth, in a general form, birth. Therefore the basic form of the language $\mathbf{t}^{\mathrm{h}}$ anaxa - $\mathbf{t}^{\mathrm{h}}$ ə nə xə // (light- God - Birth) means language born of God's light wisdom(lucid). And indeed the first common (uniform) language of the physical manifestation of the Supreme Creator - language suggested by the nature (its wisdom).

\section{d) From Georgian (same New Iberian):}

Snow in absolute darkness is so clearly visible that it may be considered the etalon of visibility, light. Therefore if they wanted to say: the most visible reality has befell upon the environ $\sim$, they expressed the given reality in the following way: no $\mathbf{t}^{\text {h}} \boldsymbol{\partial}$ ro (water-snow-is). So the contemporary word came to existence nat ${ }^{\mathrm{h}} \mathbf{e l i}\left(\right.$ nət $^{\mathrm{h}}$ əro $\rightarrow$ nət $^{\mathrm{h}}$ əre $\rightarrow$ nat $^{\mathrm{h}}$ ere $\rightarrow$ nat $^{\text {hele }} \rightarrow$ nat $^{\text {heli) }}$. 
I.e. water befallen as visible snow, as the fresh water is invisible in the dark of the night, i.e. it is dark (Georg. - bneli. Thus, the given reality used to be expressed in the following way bə nə rə (pouring _ water _ is). bə nə rə $\rightarrow$ bənə re $\rightarrow$ bne re $\rightarrow$ bnele $\rightarrow$ bneli; If they

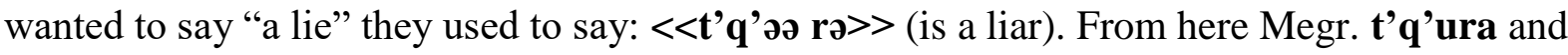
Georgian t'q'uili; The essence of the notions "New" and "old" can not be determined by the rapid wearing of the newly made object or preservance of the quality of centuries old object, therefore if they wanted to say $<<$ axali $>>$ (new), they used to sai: $<<$ a xə rə>> (was born is) and if they wanted to say the word 'zveli (old), they used to say 'zəə rə $\sim$ (is placed is) (zəə rə $\rightarrow$ zue re $\rightarrow$ zuele $\rightarrow$ zueli $\rightarrow$ zveli and etc.

Now let us have a look at the situation between the words having derived from the basic words ( $\mathrm{k}^{\prime} \mathrm{t}^{\mathrm{h}} \mathrm{ili}$ da sa-k'ut $\mathrm{t}^{\mathrm{h}}$ ari) (in the word $\mathrm{k}^{\prime} \mathrm{et}^{\mathrm{h}}{ }^{\mathrm{ili}}$ sound $\mathrm{I}$ is a result of the relaxation, or softening of the sound.

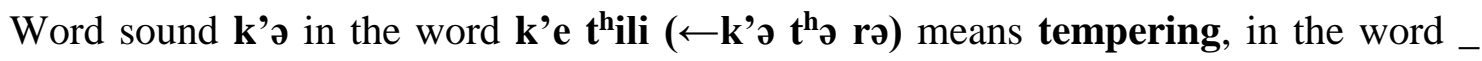

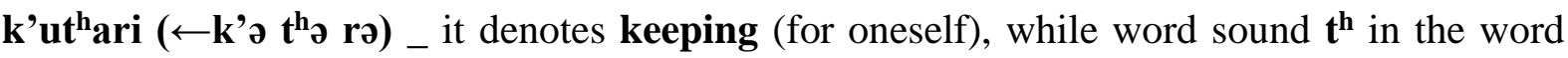
$\mathbf{k}^{\prime} \mathbf{e t}^{\mathrm{h}} \mathbf{\text { ili }}$ means light, divine wisdom, in a word _ $\mathbf{k}^{\prime} \mathbf{u t}^{\mathbf{h}} \mathbf{a r i}$ it denotes a head. The word $\mathbf{k}^{\prime} \mathbf{t}^{\mathrm{h}}{ }^{\mathrm{ili}}$, means literally: tempering of light wisdom is and indeed the best deed in the human behavior, tempering of light and wisdom. The rest, in comparison, are nothing but rendering

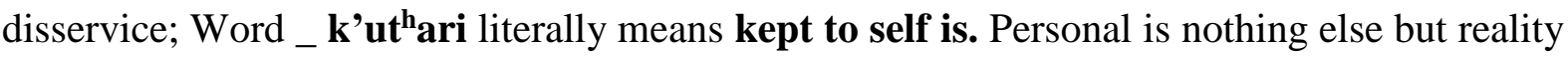
kept for self; Iberian word $\mathbf{k}^{\mathbf{}^{\prime} \mathbf{i t}} \mathbf{h}_{\mathbf{i}}\left(\leftarrow \mathbf{k}^{\prime} \boldsymbol{\jmath} \mathbf{t}^{\mathbf{h}} \boldsymbol{\partial}=\mathbf{k e p t}\right.$ to self), finger in Georgian, a part for keeping something for self.

As we have seen, it is clear from the analyzed words there is a live link between the lexis of Pre-Nostratic and contemporary Iberian language.

\section{Conclusion}

Proceeding from the abovesaid we may conclude that if a word has corresponding words in various languages, it means that their common basic form was conceived in the era of functioning of the primary uniform (common) language and their meanings could be determined by the meanings of the word sounds and sound harmonious complexes, existing in the Iberian language. If the word has no corresponding forms in other languages (or they 
may not be studied yet) but if the method we have elaborated and the application of the word sounds, existing in Iberian language as well as use of word sound meanings, existing in the Iberian language to determine its precise etymology, it points to the fact that it was conceived in the era of the first common language and has been formed through the further connection and linking of the lexis of the period.

Therefore the given method allows to determine the basic forms of all corresponding words that are included into the vocabulary of Nostratic languages, the basis of obtaining their meanings, i.e. the lexis used in the era of common speech and accordingly reconstruct PreNostratic language, same as the first primary, common language of the mankind.

Besides, the humble work is noteworthy for paving the way to the solution of the problem, regarded unsolvable in Linguistics, namely the reconstruction of the Primary, common language of the mankind, which in our view is a further important step towards the perception of the unsolved mystery and accordingly further spiritual-moral development of the mankind.

\section{References:}

1. Bible, (1991) New Testament and the psalms, Institute for Bible Translation axali aRTqma da fsalmunebi, stokholmi, bibliis Tangmnis instituti (biblia (1991) axali aykhma da phsalmunebi, Stok'holmi, bibliis $\mathrm{t}^{\mathrm{h}}$ argmnis instituti);

2. Bomhard, A. (2018) A Comprehensive introduction to Nostratic Comparative linguistics, with cpecial Reference to indo - European, volume 1.2. third revised corrected and expanded edition, florence, sc;

3. Gamkrelidze T. Machavariani G. (1965) System of sonants and ablaut in Kartvelian languages Tbilisi "Mecniereba" sonatTa sistema da ablauti qarTvelur enebSi, Tbilisi, 'mecniereba (Gamq'relize, T. Mač'avariani, G. (1965) sonant't $\mathrm{t}^{\mathrm{h}} \mathrm{a}$ sist'ema da ablaut'i kharthvelur enebši, Tbilisi "mecniereba"); 
4. Gamkrelidze T. and others (2003) Course of theoretical linguistics, Tbilisi, Tbilisi State University Teoriuli enaTmecnierebis kursi, Tbilisi, Tbilisis saxelmwifo universiteti (Gamq'relize, T. da sxv. theoriuli enat ${ }^{\mathrm{h}}$ mecnierebis k'ursi, Tbilisi, Tbilisis saxelmc'ip ${ }^{\mathrm{h}} \mathrm{o}$ universit'et'i);

5. Dolgopolsky,A. (1971-72) Which languages are related to European? Science and humanity, international annual 106-118 Долгопольский, А. (1971-72) Какие языки родственны европейским? журнал - Наука и человечество, международный ежегодник, 106-118.

6. Takaishvili, E. (1948) When did the Iberian state changed to Georgian state, a journal Mnatobi, \#8, 1948. TayaiSvili, e. (1948) rodis Seicvla iberTa saxelmwifo qarTvelTa saxelmwifod, J-li mnaTobi, \#8, 1948. $\mathrm{T}^{\mathrm{h}} \mathrm{aq}$ 'aišvili, E. (1948) Rodis šeicvala ibert ${ }^{\mathrm{h}_{\mathrm{a}}}$ sexelmc'ip ${ }^{\mathrm{h}}$ k $\operatorname{krt}^{\mathrm{h}} \mathrm{velt}^{\mathrm{h}}$ a saxelmc'ip ${ }^{\mathrm{h}}$ od, źurnali Mnat ${ }^{\mathrm{h}}$ obi, \#8, 1948.

7. Nebieridze G. (1991) Introduction to Linguistics, Tbilisi, "Ganatleba" enaTmecnierebis Sesavali, Tbilisi, 'ganaTleba (Nebierize, G. (1991) enat ${ }^{\mathrm{h}}$ mecnierebis sesavali, Tbilisi, "ganat ${ }^{\mathrm{h}}$ leba");

8. Orbeliani S. (1991-1993) Georgian Dictionary, V. I, II, Georgia’s Academy of Sciences, Tbilisi, "Merani" saqarTvelos mecnierebaTa academia, Tbilisi, 'merani (Orbeliani, S. (1991-1993) lek $\mathrm{k}^{\mathrm{h}}$ sik'oni $\mathrm{k}^{\mathrm{h}} \operatorname{art}^{\mathrm{h}} \mathrm{uli}$, $\mathrm{t}^{\prime}$. I, II. Sak $\operatorname{art}^{\mathrm{h}}$ velos mecnierebat ${ }^{\mathrm{h}} \mathrm{a}$ ak'ademia, Tbilisi, "merani");

9. Chikobava A. (1950-1964) Explanatory Dictionary of the Georgian Language, V. IVII, Tbilisi. Georgia's Academy of Sciences qarTuli enis ganmartebiTi leqsikoni, t. I $\div$ VIII, Tbilisi, saqarTvelos mecnierebaTa akademia (Cikhobava, A. (1950-1964) Kharthuli enis ganmart'ebithi lekhsik;oni, t'. I-VIII. Tbilisi, Sakharthvelos mecnierebatha ak'ademia);'

10. Fenrich, H. , Sarjveladze, Z. (2000) Etimological Dictionary of Kartvelian lanfguages, Tbilisi, S.S. Orbeliani State Pedagogical Institute. qarTvelur enaTa etimologiuri leqsikoni, Tbilisi, s. s. orbelianis saxelobis saxelmwifo pedagogiuri instituti ( $\mathrm{P}^{\mathrm{h}}$ enrixi, H.,

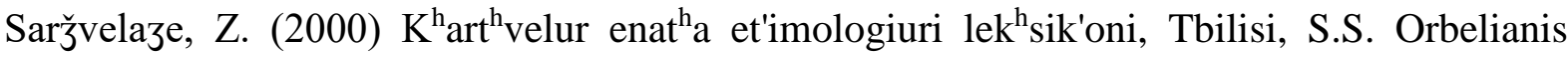
saxelobis saxelmc'ip ${ }^{\mathrm{h}} \mathrm{o}$ p'edagogiuri instituti); 
11. Dzadzamia, M. Dzadzamia Ts. (1997) Mystery of the Language Origin, Zugdidi, Zugdidi Independent University enis warmoSobis saidumloeba, zugdidi, zugdidis damoukidebeli universiteti (zazamia, M., зazamia, C. (1997) enis c'armošobis saidumloeba, Zugdidi, Zugdidis damouk'idebeli universit'eti);

12. Dzadzamia, M. Dzadzamia Ts., Vakhania V. (2007) Megrelian Language Lexis and word Origins, V. I, Tbilisi, Abkhazian Academy of Sciences megruli enis leqsika da sityvaTwarmomavloba, t. I, Tbilisi, afxazeTis mecnierebaTa akademia (zazamia, M., zazamia, C., Vaxania, V. (2007) megruli enis lek ${ }^{\mathrm{h}}$ sika da sit'q'vat ${ }^{\mathrm{h}} \mathrm{c}^{\prime}$ armomavloba, t'. I, Tbilisi, ap ${ }^{\mathrm{h}} \mathrm{x}$ asetis mecnierebat ${ }^{\mathrm{h}} \mathrm{a}$ ak'ademia. 